\title{
Microencapsulation of cellular aggregates composed of differentiated insulin and glucagon-producing cells from human mesenchymal stem cells derived from adipose
} tissue

Claudia Jara ${ }^{1}$, Felipe Oyarzun-Ampuero ${ }^{2,3}$, Flavio Carrión ${ }^{4}$, Esteban González-Echeverría ${ }^{1}$, Claudio Cappelli ${ }^{5}$ and Pablo Caviedes ${ }^{1,6^{*}}$ (1)

\begin{abstract}
Background: In type I diabetes mellitus (T1DM) pancreatic $\beta$ cells are destroyed. Treatment entails exogenous insulin administration and strict diet control, yet optimal glycemic control is hardly attainable. Islet transplant could be an alternative in patients with poor glycemic control, but inefficient islet purification and autoimmune response of patients is still a challenge. For these reasons, it is necessary to explore new cellular sources and immunological isolation methods oriented to develop T1DM cell-based therapies.

Aims: We postulate human adipose-derived stem cell (hASC) as an adequate source to generate pancreatic islet cells in vitro, and to produce islet-like structures. Furthermore, we propose microencapsulation of these aggregates as an immunological isolation strategy.

Methods: hASC obtained from lipoaspirated fat tissue from human donors were differentiated in vitro to insulin (Ins) and glucagon (Gcg) producing cells. Then, insulin producing cells (IPC) and glucagon producing cells (GPC) were cocultured in low adhesion conditions to form cellular aggregates, and later encapsulated in a sodium alginate polymer. Expression of pancreatic lineage markers and secretion of insulin or glucagon in vitro were analyzed.

Results: The results show that multipotent hASC efficiently differentiate to IPC and GPC, and express pancreatic markers, including insulin or glucagon hormones which they secrete upon stimulation (fivefold for insulin in IPC, and fourfold for glucagon, compared to undifferentiated cells). In turn, calculation of the Feret diameter and area of cellular aggregates revealed mean diameters of $\sim 80 \mu \mathrm{m}$, and $65 \%$ of the aggregates reached $4000 \mu \mathrm{m}^{2}$ at $72 \mathrm{~h}$ of formation. IPC/GPC aggregates were then microencapsulated in sodium-alginate polymer microgels, which were found to be more stable when stabilized with $\mathrm{Ba}^{2+}$, yielding average diameters of $\sim 300 \mu \mathrm{m}$. Interestingly, $\mathrm{Ba}^{2+}$-microencapsulated aggregates respond to high external glucose with insulin secretion.
\end{abstract}

\footnotetext{
*Correspondence: pcaviede@med.uchile.cl

${ }^{1}$ Programa de Farmacología Molecular y Clínica, ICBM, Facultad

de Medicina, Universidad de Chile, Independencia 1027., Casilla 7,

Clasificador № 7, 8389100 Santiago, Chile

Full list of author information is available at the end of the article
}

c) The Author(s) 2020. This article is licensed under a Creative Commons Attribution 4.0 International License, which permits use, sharing, adaptation, distribution and reproduction in any medium or format, as long as you give appropriate credit to the original author(s) and the source, provide a link to the Creative Commons licence, and indicate if changes were made. The images or other third party material in this article are included in the article's Creative Commons licence, unless indicated otherwise in a credit line to the material. If material is not included in the article's Creative Commons licence and your intended use is not permitted by statutory regulation or exceeds the permitted use, you will need to obtain permission directly from the copyright holder. To view a copy of this licence, visit http://creativeco mmons.org/licenses/by/4.0/. The Creative Commons Public Domain Dedication waiver (http://creativecommons.org/publicdomain/ zero/1.0/) applies to the data made available in this article, unless otherwise stated in a credit line to the data. 
Conclusions: The IPC/GPC differentiation process from hASC, followed by the generation of cellular aggregates that are later microencapsulated, could represent a possible treatment for T1DM.

Keywords: Adipose-derived mesenchymal stem cells, Cellular aggregates, Cellular differentiation, Cell therapy, Diabetes, Microencapsulation

\section{Background}

Type I diabetes mellitus (T1DM) is an autoimmune and degenerative disease characterized by an autoimmune reaction against pancreatic $\beta$ cells [1]. Glycemic control by conventional parenteral insulin (Ins) therapy accompanied by strict diet and controlled physical exercise is often inefficient, as the loss of $\beta$ cells entails the absence of paracrine regulation between $\alpha$ and $\beta$ cells [2].

A promising therapy had been proposed by results from the Edmonton protocol, which utilized glucocorticoid-free immunosuppression combined with infusion of an adequate mass of freshly prepared post-mortem pancreatic islets. With this treatment, $44 \%$ of treated subjects became insulin independent after 1 year of transplantation [3]. However, at present, this therapy is restricted to patients with poor or no metabolic control $[4,5]$. Indeed, the shortage of donors and technical limitations entailed in pancreatic islet isolation make the massive implementation of this therapy difficult [6]. Also, activation of the immune system against the transplanted islets results in the gradual death of the graft [6]. Further, immunosuppressants used, such tacrolimus and/or sirolimus, are diabetogenic, and reportedly have other undesirable side effects such as mouth ulcers, diarrhea and acne [7]. Recently, new immunosuppression protocols have been tested, which include different $\mathrm{T}$ and $\mathrm{B}$-cell depleting agents [8]. In addition to the use of long-term glucocorticoid-free immunosuppressants, immunological isolation of the graft by encapsulation has been proposed as a solution [6]. On the other hand, encapsulation of pancreatic islets provides a physical barrier against immune system activation [9]. Thus, it is essential to find new cellular sources and immunological isolation methods to face these limitations.

As a cellular source, we propose the use of mesenchymal stem cells (MSC), a population of multipotent cells present in almost all adult tissues [10]. MSC cells derived from human adipose tissue, or "adipose-derived stem cells" (hASC) are easier to purify by using less invasive methods [11, 12]. Previous studies showed that hASC can be differentiated to insulin producing cells (IPC) [13, 14], and ESC can be differentiated to glucagon producing cells (GPC) [15]. Other groups have reported generation of islet-like cell aggregates (ICA) $[16,17]$ to reestablish not only $\beta$-cell function, but also part of the necessary paracrine regulation between $\alpha$ and $\beta$ cells [18]. However, the activation of the immune system against grafts remains a major limitation for this approach.

On the other hand, cellular encapsulation is a new strategy to provide immune isolation to avoid host rejection of grafts. Among the current existing techniques, microencapsulation entails several benefits: it allows the encapsulation of single islets by generation of spherical gels of micrometric size and with optimal surface/volume ratio, as compared to macroencapsulation systems [19]. Microcapsules indeed facilitate a rapid exchange of oxygen, glucose, insulin and nutrients between the capsule and the environment [19]. One of the most used biomaterials for encapsulation is sodium alginate, a natural copolymer that changes its physical state, from liquid to gel, in presence of divalent cations (mainly $\mathrm{Ba}^{2+}$ or $\mathrm{Ca}^{2+}$ ) [19]. It has been reported that encapsulation of islets in $\mathrm{Ba}^{2+}$-alginate preserve islet function in vitro with similar regulated insulin secretion compared to non-encapsulated islets [19]. In addition, Safley et al. demonstrated in vivo biocompatibility of $\mathrm{Ba}^{2+}$-alginate microgels [20], and others in vivo studies have demonstrated that $\mathrm{Ba}^{2+}$-alginate microgels provide long term immunoprotection in animal models [21-23]. In previous studies, successful allotransplant of parathyroid tissue encapsulated in $\mathrm{Ba}^{2+}$-alginate was reported in a patient suffering of severe hypocalcemia due to an iatrogenic parathyroid resection. In this case, the grafted tissue showed functionality for at least 20 months with a mild requirement of oral calcium supplementation [24, 25]. Considering this same principle, we hypothesized that we could generate functional, microencapsulated IPC/GPC aggregates in vitro, from IPC and GPC differentiated from hASC.

\section{Materials and methods}

\section{Isolation and cell culture of hASC}

This study was approved by the Research Ethics Committee, Faculty of Medicine, University of Chile. Adipose tissue was obtained from five donors aged between 30 and 45 years undergoing abdominal liposuction cosmetic surgery. Informed consent was obtained from all participants. hASC were obtained from lipoaspirated fat tissue, the tissue was digested by type I collagenase $0.2 \%$ $\mathrm{p} / \mathrm{v}$ (Worthington, NJ, USA. Catalog number LS004196) and the stromal vascular fraction (SVF) was cultured in DMEM:F12 1:1 (Gibco ${ }^{\mathrm{TM}}$, Dublin, Ireland. Catalog number 12500062) medium supplemented with $10 \%$ 
$\mathrm{v} / \mathrm{v}$ fetal bovine serum (FBS), denominated supplemented medium, at $37^{\circ} \mathrm{C}$ and $5.0 \% \mathrm{CO}_{2}$.

\section{Differentiation to IPC from $\mathrm{hASC}$ in vitro}

hASC were differentiated in vitro to IPC using a twostage protocol [13, 14], with discrete modifications. Cells were stimulated for 7 days with DMEM high glucose $(25 \mathrm{mM})\left(\right.$ Gibco $^{\mathrm{TM}}$, Dublin, Ireland. Catalog number 12100046); followed by 14 days with DMEM low glucose $(5 \mathrm{mM})\left(\right.$ Gibco $^{\mathrm{TM}}$, Dublin, Ireland. Catalog number 31600034). Both media were supplemented with $2 \mathrm{nM}$ activin A (Prospecbio, Rehobot, Israel. Catalog number CYT-145), $10 \mathrm{mM}$ nicotinamide (Sigma-Aldrich, Merck KGaA, Darmstadt, Germany. Catalog number N0636) and $10 \mathrm{nM}$ glucagon like peptide (GLP-1) (Prospecbio, Catalog number HOR-284). However, we used $2 \%$ $\mathrm{v} / \mathrm{v}$ FBS instead of $10 \% \mathrm{v} / \mathrm{v}$ as a supplement to differentiation medium during all differentiation stages, Fig. 1a.

\section{Differentiation to GPC from $\mathrm{hASC}$ in vitro}

GPC were obtained by the protocol reported for Rezania et al. [15] with modifications. The protocol consists of 6 stages: stage 1, incubated for 4 days with RPMI 1640 (Gibco $^{\mathrm{TM}}$. Catalog number 31800), bovine serum albumin (BSA) (Sigma-Aldrich, catalog number A9418) 2\%, activin A $100 \mathrm{ng} / \mathrm{mL}$ (Prospecbio), Wnt3a $20 \mathrm{ng} /$ $\mathrm{mL}$ (Sigma-Aldrich. Catalog number H17001), FGF2 $8 \mathrm{ng} / \mathrm{mL}$ (Prospecbio. Catalog number CYT-085). Stage 2, incubated for 2 days with DMEM-F12 medium with BSA 2\%, FGF7 $50 \mathrm{ng} / \mathrm{mL}$ (Prospecbio. Catalog number
CYT-303), Cyclopamine-KAAD $0.25 \mu \mathrm{M}$ (SCBT, Dallas, Tx, USA. Catalog number sc-200929). Stage 3, incubation for 4 days with DMEM-F12 medium, Cyclopamin-KAAD $0.25 \mu \mathrm{M}$, retinoic acid (RA) $2 \mu \mathrm{M}$ (Sigma-Aldrich. Catalog number R2625), FGF7 $50 \mathrm{ng} /$ $\mathrm{mL}$ (Prospecbio), Noggin $100 \mathrm{ng} / \mathrm{mL}$ (Prospecbio. Catalog number CYT-475). Stage 4, incubation for 3 days with DMEM:F12 medium, Inhibitor II ALK5 $1 \mu \mathrm{M}$ (SCBT. Catalog number sc-221234), Noggin $100 \mathrm{ng} /$ $\mathrm{mL}$, DAPT $1 \mu \mathrm{M}$ (SCBT. Catalog number sc-201315). Stage 5, incubation for 7 days with DMEM/F12 medium, inhibitor II ALK5 $1 \mu \mathrm{M}$. Stage 6, incubation for 7 days with DMEM F12 medium. However, we used $2 \% \mathrm{v} / \mathrm{v}$ FBS instead of $1 \%$ B27 as a supplement to differentiation medium during stages 3 to 6 , Fig. $1 \mathrm{~b}$.

\section{Formation of cell aggregates}

The formation of cells aggregates was induced applying a proprietary protocol that subjects cells to low adherence conditions and progressive clustering, as previously described [26]. Briefly, differentiated IPC and GPC cells were incubated in a 4:1 ratio respectively, using $10^{5}$ total cells, under conditions of non-adherence. This protocol combines (1) the use of bacteriological plates with low electrical charge, and (2) culturing in low $\mathrm{Ca}^{2+}$ and $\mathrm{Mg}^{2+}$ using a special formulation of Eagle Minimum Essential Medium, Joklik Modification (Sigma-Aldrich. Catalog number M0518) and (3) reduced concentration of FBS $(2 \% \mathrm{v} / \mathrm{v})$ for up to 7 days.

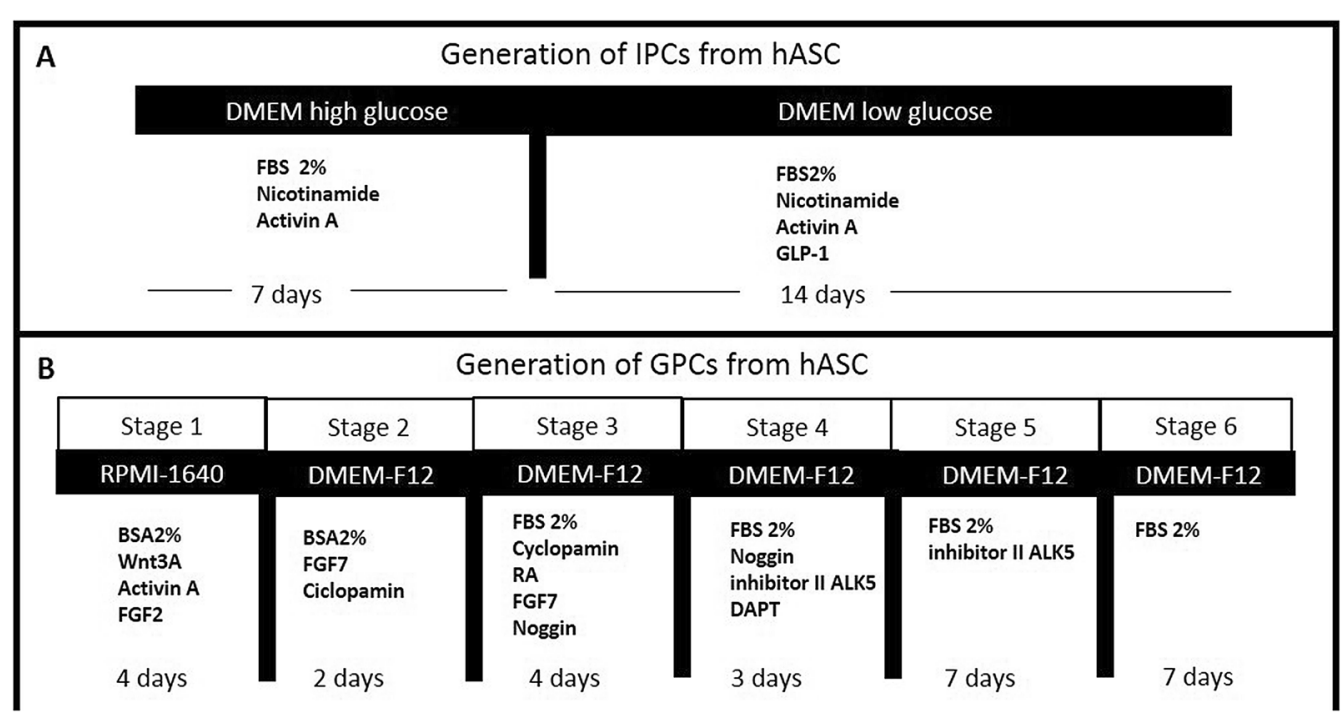

Fig. 1 Schematic representation of differentiation protocols from hASC to IPC and GPC. a IPC differentiation protocol in two stages during 21 days. b GPC differentiation protocol in six stages during 27 days. FBS: fetal bovine serum, GLP-1: glucagon like-peptide 1, BSA: Bovine serum albumin, FGF2: fibroblastic growth factor 2, RA: retinoic acid, FGF7: fibroblastic growth factor 7, ALK 5: TGF $\beta$ type I receptor kinase, DAPT: Gamma-Secretase Inhibitor IX (N-[N-(3,5-Difluorophenacetyl-L-alanyl)]-S-phenylglycine t-butyl ester) 


\section{Immunofluorescent staining}

\section{Immunofluorescence of adherent cells}

Undifferentiated and differentiated cells were grown in glass coverslips and fixed for 10 min with $4 \%$ paraformaldehyde (PFA) (Sigma-Aldrich. Catalog number 158127) in phosphate buffer saline (PBS) at room temperature, washed, and then permeabilized with $0.3 \%$ triton X-100 (Sigma-Aldrich. Catalog number T8787) for $10 \mathrm{~min}$ and incubated with $3 \%$ BSA in PBS (to block non-specific binding) for $45 \mathrm{~min}$. Cells were then incubated overnight at $4{ }^{\circ} \mathrm{C}$ with Abcam primary antibodies (Abcam, Cambridge, UK) (Ms anti-C44 Catalog number ab6124, Goat anti-Pdx1 Catalog number ab47383, Rb anti-Ngn3 Catalog number ab38548, GPig anti-Ins Catalog number ab7842, Mouse anti-Gcg Catalog number ab 10988, and Goat anti-Vim Catalog number V-4630 (Sigma-Aldrich). Cells were then washed with PBS and incubated with corresponding secondary antibodies for $90 \mathrm{~min}$ at RT (Dnk anti-mouse Catalog number ab96875, Dnk antigoat Catalog number ab96933, Dnk anti-rb Catalog number ab96919, Dnk anti-GPig Catalog number ab150185, Goat anti-mouse Catalog number ab6787, Dnk anti-goat Catalog number ab96931) (Abcam). Cells were washed with PBS and then incubated with Hoechst (Millipore, Burlington, MA, USA) 1:500 for $5 \mathrm{~min}$ at RT. Covers were washed and mounted in slides with fluorescence mounting medium DAKO (Agilent, CA, USA. Catalog number S302380). The images were analyzed using confocal microscopy (LSM700, Zeiss) and the ImageJ public domain software.

\section{Immunofluorescence of cell aggregates}

Prior to immunofluorescence, cell aggregates formed after $72 \mathrm{~h}$ were fixed in 4\% PFA for $1 \mathrm{~h}$ and added to $1 \%$ liquid low melting agarose (Sigma-Aldrich, Catalog number A9414) in PBS $\left(50^{\circ} \mathrm{C}\right)$. To obtain cell blocks, the agarose-cell mix was centrifuged at $1500 \mathrm{rpm}$ for $5 \mathrm{~min}$ at RT. Cryostat sections of $6 \mu \mathrm{m}$ were submitted to conventional IFI and visualized by confocal microscopy (LSM 700, Carl Zeiss).

\section{ELISA assay}

To test if the hormonal release of IPC, GPC cells and aggregates was glucose-dependent, two glucose concentrations (2 $\mathrm{mM}$ and $25 \mathrm{mM}$ ) were assayed. After pre-incubation with Krebs-Ringer buffer (KRB) without glucose $\left(120 \mathrm{mM} \mathrm{NaCl}, 5 \mathrm{mM} \mathrm{KCl}, 2,5 \mathrm{mM} \mathrm{CaCl}_{2}\right.$, 1,1 mM MgCl $2,25 \mathrm{mM} \mathrm{NaHCO}_{3}, 10 \mathrm{mM}$ HEPES, 0.1\% BSA) at $37^{\circ} \mathrm{C}$ for $2 \mathrm{~h}$, the cells were incubated with KRB containing $2 \mathrm{mM}$ glucose at $37^{\circ} \mathrm{C}$ for $4 \mathrm{~h}$. To induce insulin release, the cells were incubated with KRB containing $25 \mathrm{mM}$ glucose for another $4 \mathrm{~h}$. Then, the respective conditioned media were collected and tested for the content of released insulin with human insulin (Mercodia, Uppsala, Sweden. Catalog number 10-1132-01) and human glucagon (Cusabio, Houston, TX, USA. Catalog number CSB-E09207h) ELISA kits.

\section{Microencapsulation of cell aggregates}

Alginate microgels were automatically produced using the dripping technique. As a polymer, $1.5 \%$ (MW medium) sodium alginate (Sigma-Aldrich. Catalog number A2033) dissolved in $0.9 \% \mathrm{NaCl}$ was used. The stabilizing solutions of barium and calcium chloride were maintained at $\mathrm{pH} 7.0$ and were composed of (in $\mathrm{mM}$ ): $\mathrm{BaCl}_{2}$ (20), $\mathrm{NaCl}$ (115), and histidine (50), or $\mathrm{CaCl}_{2}$ (40), $\mathrm{NaCl}$ (85), HEPES (10). First, $1 \mathrm{~mL}$ of sodium alginate solution $(1.5 \% \mathrm{w} / \mathrm{v})$ was mixed with $2 \times 10^{4}$ cellular aggregates previously filtered through $40 \mu \mathrm{m}$ and $120 \mu \mathrm{m}$ sieves. This anionic suspension was pumped using an Encapsulator B-395Pro (Büchi, Flawil, Switzerland), equipped with a $150 \mu \mathrm{m}$ nozzle over a stirring barium or calcium chloride solution for $30 \mathrm{~s}$, with a dripping flow of $32 \mathrm{~mL} / \mathrm{min}, 3000 \mathrm{~Hz}$ frequency and $1000 \mathrm{~V}$ voltage, as previously reported $[27,28]$. After its formation, the microgels were washed with $0.9 \% \mathrm{NaCl}$ and incubated in DMEM/F12 medium supplemented with 10\% FBS in cell culture conditions $\left(37^{\circ} \mathrm{C}, 5.0 \% \mathrm{CO}_{2}\right)$. Additionally, rupture of the microgels was evaluated by dissolving the alginate with a solution composed of solution composed of $100 \mathrm{mM}$ sodium citrate, $10 \mathrm{mM}$ MOPS and $27 \mathrm{mM} \mathrm{NaCl}$ according to reports from Wang et al. [29].

\section{Statistical analysis}

For the experiments of cell aggregate formation and encapsulation of BSA or SpA proteins, statistical analysis was performed using one-way ANOVA followed by Student's $t$ test as post hoc. Student t test was used in Ins or Gcg release tests. Differences were deemed statistically significant for $\mathrm{p}$-values of less than 0.05 .

\section{Results}

\section{Characterization of hASC}

The SVF obtained from each patient was used as a source of MSC, denominated hASC, and characterized following the mesenchymal stem cell minimal criteria described by Dominici et al. [30]. To define these cells as a population of hASC, we validated the specific pattern of surface markers associated to these cells by flow cytometry (Additional file 1: Table S1). The results of hASC characterization obtained from 5 donors confirmed that these cells were positive for expression of CD90, CD73, CD105, CD44, and CD29, while lacking expression of CD45, CD34, CD19 and HLA-DR surface markers. Moreover, we tested the differentiation potential of these cells to adipogenic, osteogenic and chondrogenic phenotype, 
and confirmed that hASC were able to differentiate to these three lineages compared to undifferentiated hASC, as evidenced by the detection of known characteristic features of differentiation such as the presence of lipidic intracellular vacuoles in adipogenic cells, calcium deposition determined by Von Kossa staining in osteogenic cells; and finally, sulfated mucines detected by alcian blue staining in chondrogenic cells (Additional file 2: Figure S1).

\section{Generation and characterization of IPC and GPC}

After application of the in vitro differentiation protocol, we performed immunofluorescence analysis in IPC and GPC, which showed presence and nuclear localization of $\beta$ cell specific transcription factors as Pdx1 and Ngn3, Fig. 2. On the other hand, hASC, expressed these markers poorly, with diffuse distribution (Fig. 2a). Moreover, IPC expressed insulin, which was not evident in hASC (Fig. 2b). Further, insulin secretion by IPC treated with external high glucose $(25 \mathrm{mM})$ increased fivefold compared to undifferentiated cells (Fig. 3a). Conversely, GPC cells express glucagon and secrete the hormone in response to low glucose concentration in the medium fourfold greater than undifferentiated cells, Fig. 3b. These results suggest that our differentiation protocol of hASC to IPC and GPC, strongly reproduce the functionality of these cells.

\section{Cell aggregate formation}

The results of IPC/GPC aggregate formation over time is shown in Fig. 4a. At $24 \mathrm{~h}$ of culture, aggregates are not yet evident. However, at $48 \mathrm{~h}$ almost all cells are aggregated. At 72 y 96 h, these formations were significantly larger. Finally, at day 7, the aggregates tend to lose their shape and cellular debris appears, suggesting cell death. The analysis by optical microscopy reveals that the area of the aggregates increased in time, Fig. $4 \mathrm{~b}$. At $24 \mathrm{~h}$, we estimated that $55 \%$ of the aggregates have an area below $2000 \mu^{2}$. At $48 \mathrm{~h}$, most aggregates (65\%) reached at least $2500 \mu \mathrm{m}^{2}$. At 72 and $96 \mathrm{~h}, 65 \%$ of the aggregates reached $4000 \mu \mathrm{m}^{2}$. By day 7 , all aggregates comprised areas from 1000 to $4000 \mu \mathrm{m}^{2}$, suggesting a slow decay of the aggregate structure at this time. Later, cell aggregates incubated at different times were filtered through $40 \mu \mathrm{m}$ and $120 \mu \mathrm{m}$ sieves to concentrate the aggregates within these sizes and evaluate the best time to obtain

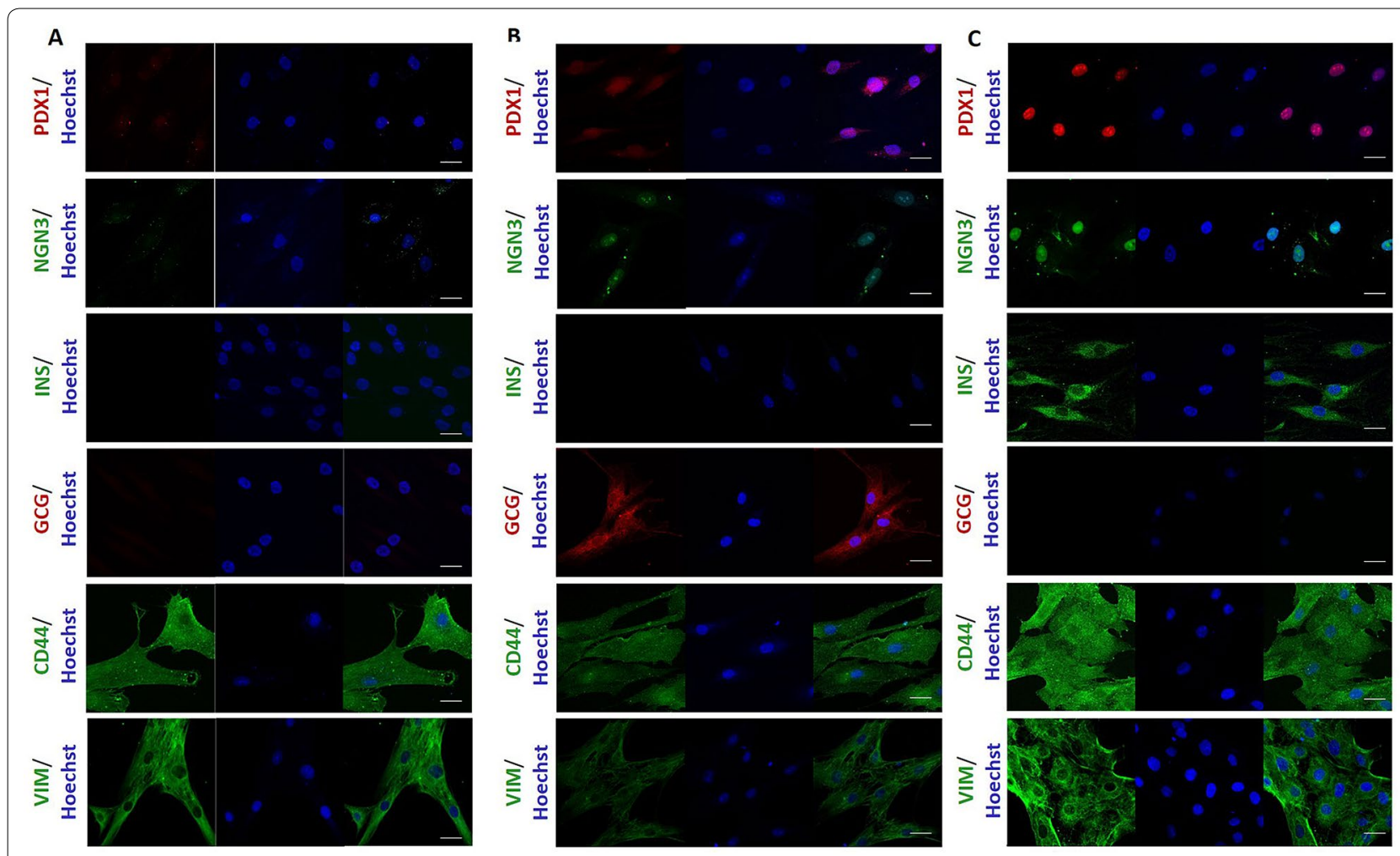

Fig. 2 Expression of differentiation markers in hASC, IPC and GPC by indirect immunofluorescence. The images shown are representative of $\mathrm{n}=3$ experiments, visualized by confocal microscopy. Nuclear staining was performed with Hoechst 1: 500 (blue). Markers analyzed were Pdx1 (red), Ngn3 (green), Insulin (green), Glucagon (red), CD44 (green) and Vimentin (green). a Markers analyzed in hASC. b Markers analyzed in IPC. c Markers analyzed in GPC. Scale bar $=20 \mu \mathrm{m}$. Pdx1 pancreatic and duodenal homeobox 1, Ngn3 neurogenin 3, Ins insulin, Gcg glucagon, Vim vimentin 

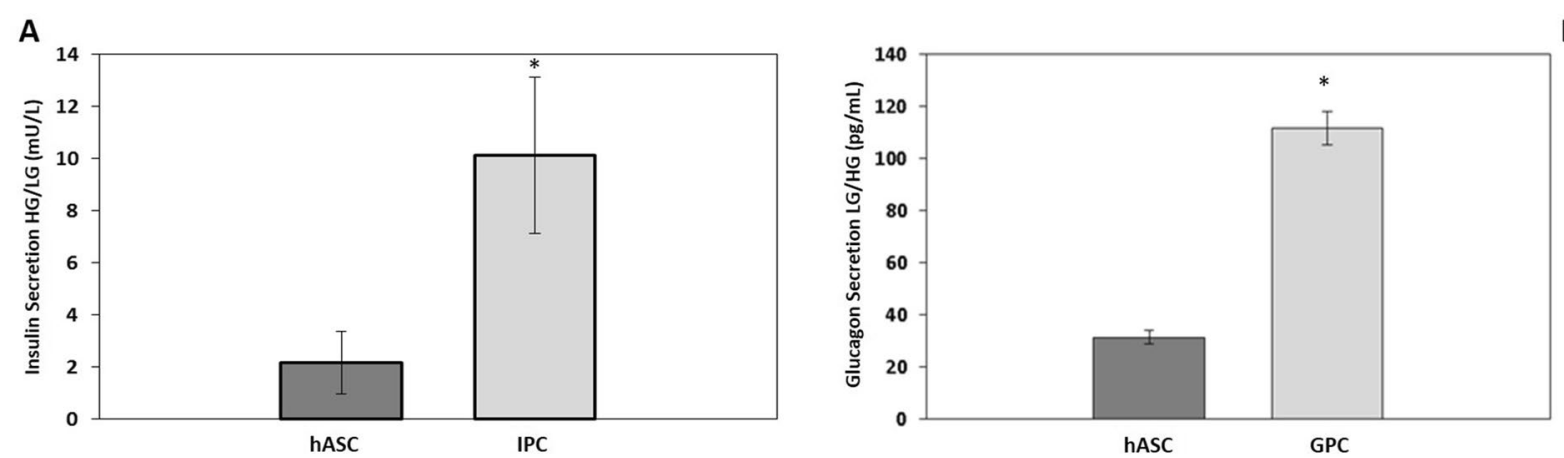

Fig. 3 Hormonal secretion in response to low or high external glucose concentration in vitro. Glucose challenge was performed by incubating the cells with low-glucose buffer ( $2 \mathrm{mM}$ ) or high-glucose buffer $(25 \mathrm{mM})$ for $4 \mathrm{~h}$. a Insulin secretion in response to high glucose in vitro. $\mathbf{b}$ Glucagon secretion in response to low glucose in vitro. $n=3$. *Significant $p<0.05$ (Student's t test)

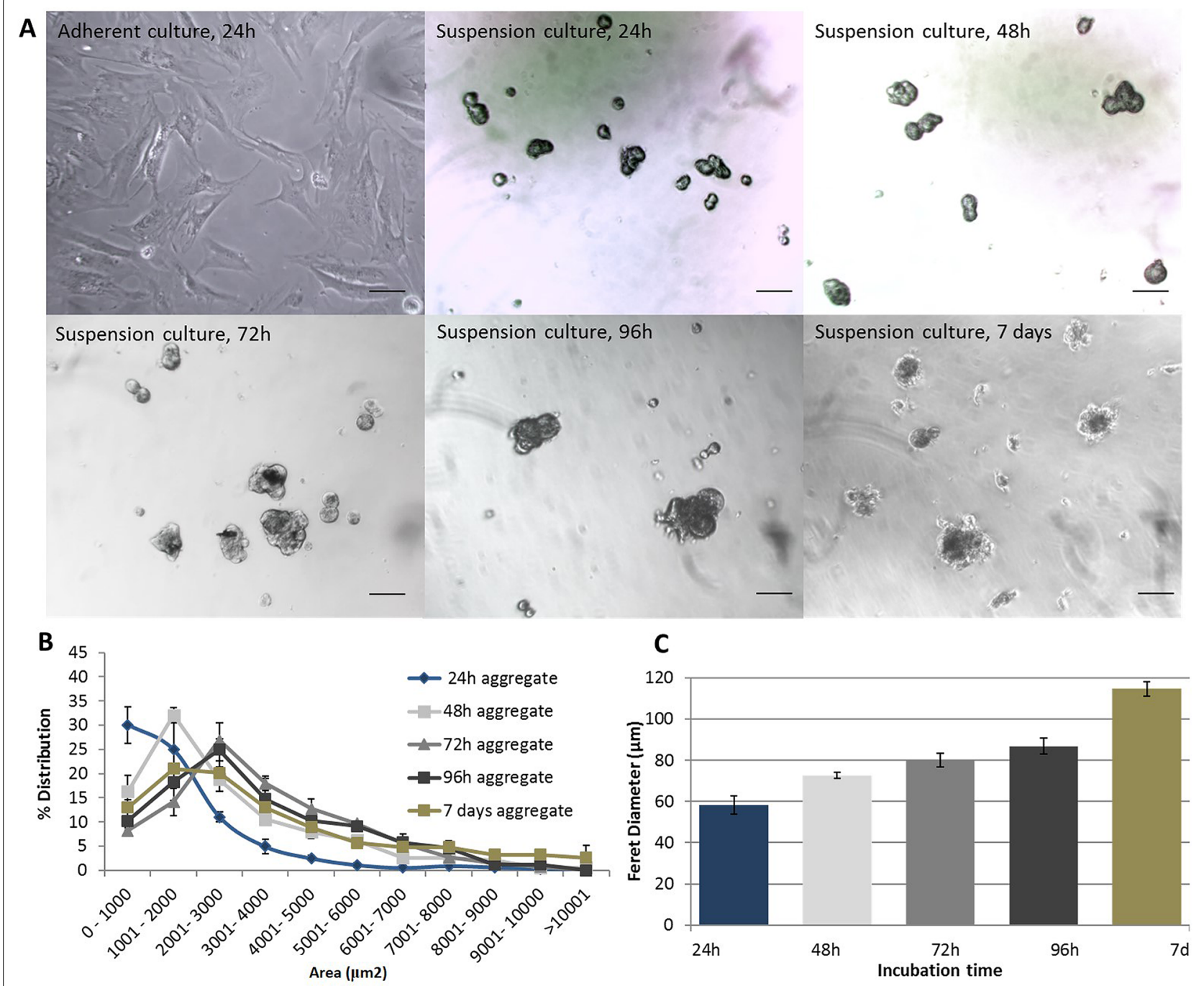

Fig. 4 Time course of IPC/GPC aggregation formation. a Optical microscopy of IPC/GPC. $\mathbf{b}$ Area distribution of the cell aggregates. $\mathbf{c}$ Feret diameter of cells aggregates. All experiments were performed at $24,48,72,96 \mathrm{~h}$ and day 7 of culture. ANOVA followed by Student's t-test, ${ }^{*} p<0.05 . n=4$.

Scale bar $=100 \mu \mathrm{m}$ 
larger aggregates in a stable manner. When calculating the diameter, we found that at $72 \mathrm{~h}$, most aggregates had similar diameters $(\sim 80 \mu \mathrm{m})$, Fig. 4c. Finally, confocal microscopy studies in cryostat sections of differentiated cell aggregates revealed the presence of Insulin and Pdx1, and very faint staining for glucagon (Fig. 5).

\section{Microcapsules of cell aggregates}

The aggregates were encapsulated in sodium alginate stabilized by $\mathrm{Ca}^{2+} \mathrm{o} \mathrm{Ba}^{2+}$ cations. Detection of alginate particle diameters by optical microscopy indicated that microgels generated were spherical, with an approximate diameter of $\sim 310 \mu \mathrm{m}$ (Fig. $6 \mathrm{a}$ and Table 1 ). To evaluate the permeability of microgels, SpA and BSA proteins (40 and $60 \mathrm{kDa}$, respectively) were previously encapsulated in $1.5 \%$ sodium alginate and stabilized by $\mathrm{Ca}^{2+}$ or $\mathrm{Ba}^{2+}$ cations, see Additional file 1. These microgels presented sizes similar (Additional file 1: Table S2) to those used to encapsulate cellular aggregates (Table 1). When then evaluated the encapsulation efficiency of our alginate microcapsules, which was estimated to be in the 54 and $58 \%$ range, that is, 54 to $58 \%$ of the total protein was encapsulated, whereas 46 to $42 \%$ of the protein remained in the stabilization medium without being incorporated into the microgel. No significant differences were found between encapsulated BSA or SpA proteins (Additional file 3: Figure S2).
Interestingly, when determining the release of $\mathrm{SpA}$ or BSA from the microgels to KRB, we observed a burst effect achieving up to of $13 \%$ of release in the first $5 \mathrm{~min}$ of incubation in both, $\mathrm{Ca}^{2+}$ or $\mathrm{Ba}^{2+}$ stabilized cations (Additional file 3: Figure S2). Then a steady state is reached at 15 and $20 \mathrm{~min}$, achieving up to $16 \%$ of protein release in both, $\mathrm{Ca}^{2+}$ or $\mathrm{Ba}^{2+}$ microgels (Additional file 3: Figure S2), without finding significant differences between microgels formed with $\mathrm{Ca}^{2+}$ or $\mathrm{Ba}^{2+}$, nor between microgels containing SpA protein or BSA.

After IPC/GPC cellular aggregates encapsulation, we observed that cell aggregates microencapsulated in $\mathrm{Ca}^{2+}$ did not adequately stabilize alginate microgels, which began to swell and degrade after $96 \mathrm{~h}$ in culture conditions. Conversely, $\mathrm{Ba}^{2+}$ stabilized microgels were stable after 7 days (Fig. 6a). IPC/GPC $\mathrm{Ba}^{2+}$ stabilized microgels were capable of secreting insulin in response to elevated glucose concentrations (HG, $25 \mathrm{mM}$ ) at 1 day (Fig. 6b). However, after 7 days in vitro, this response decayed, and no significant differences were found thereon with respect to control (Fig. 6c).

\section{Discussion}

Differentiation to IPC can be achieved from various cellular sources such as: embryonic stem cells (ESC) [31], induced pluripotent stem cells (iPSCs) [32] and MSC derived from adult tissue, as adipose (hASC) [13, 14],

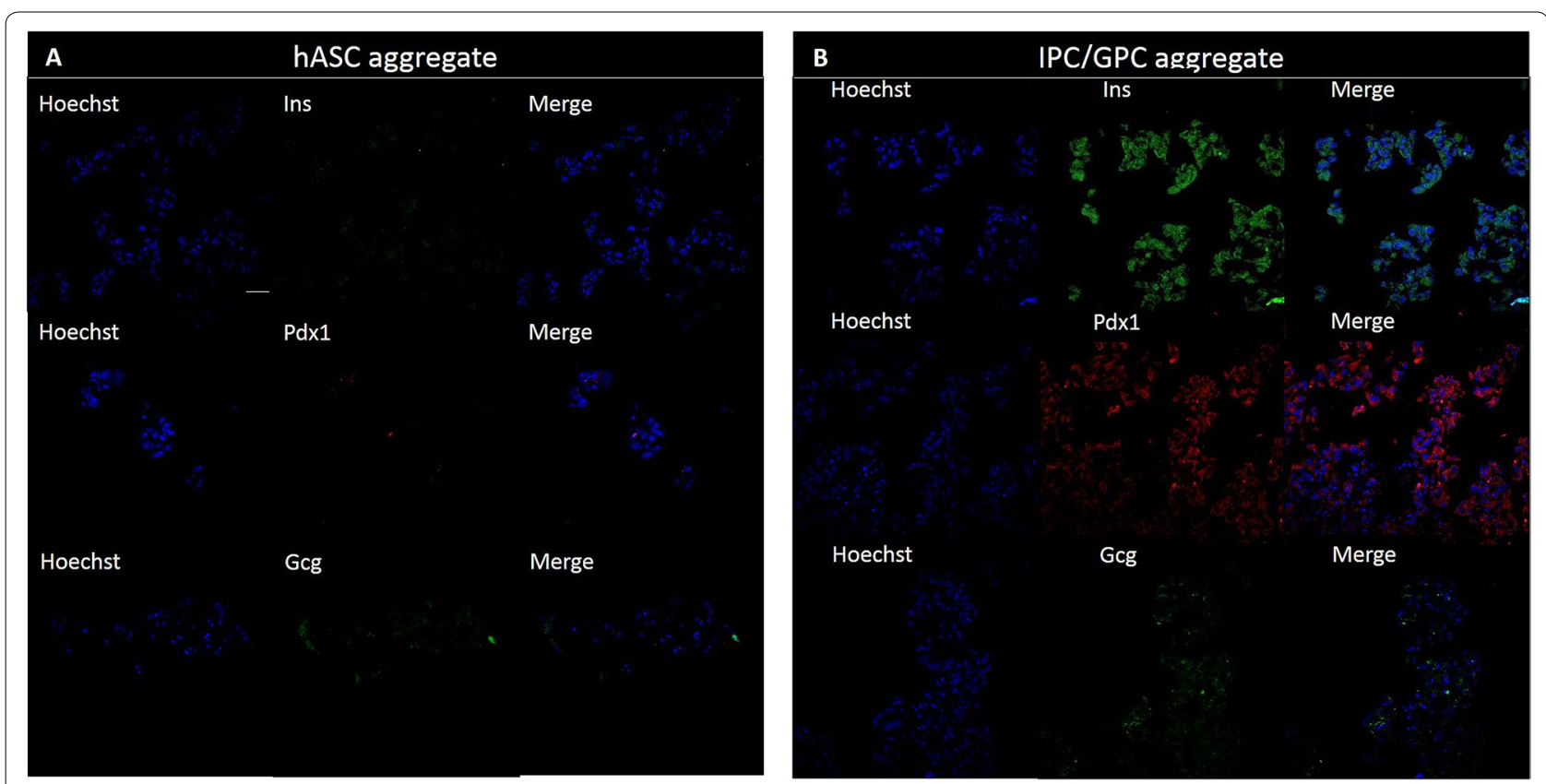

Fig. 5 Expression of pancreatic markers in hASC and IPC/GPC aggregates at $72 \mathrm{~h}$ culture by indirect immunofluorescence. The images shown are representative of $n=3$ experiments, visualized by confocal microscopy. The left panel corresponds to cell aggregates of hASC and the right panel to cell aggregates of IPC/GPC. a Insulin (green). b Pdx1 (red) and c Gcg (green). Hoechst staining 1:500 (blue) was performed to detect nuclei, $n=3$. Scale bar $=40 \mu \mathrm{m}$ 


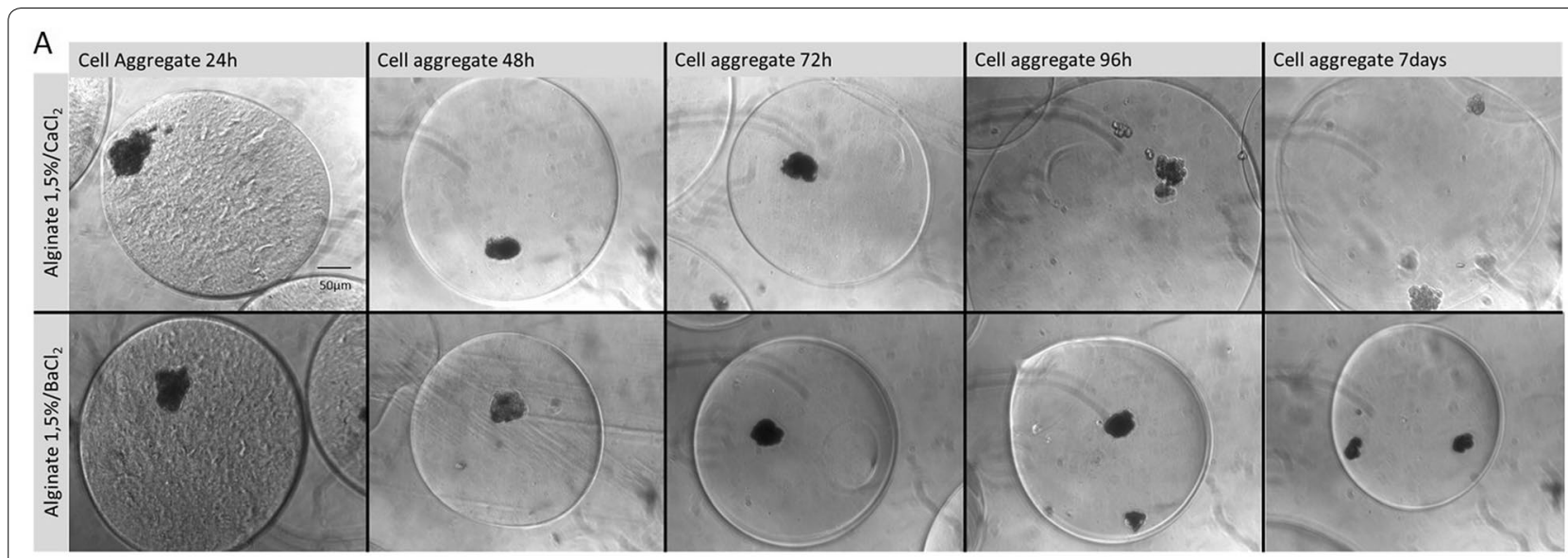

B

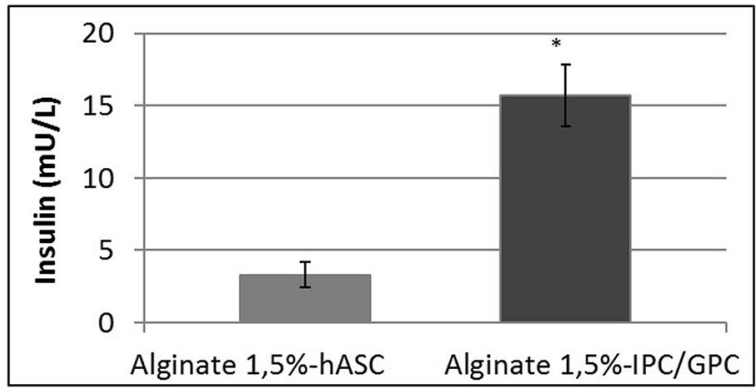

C

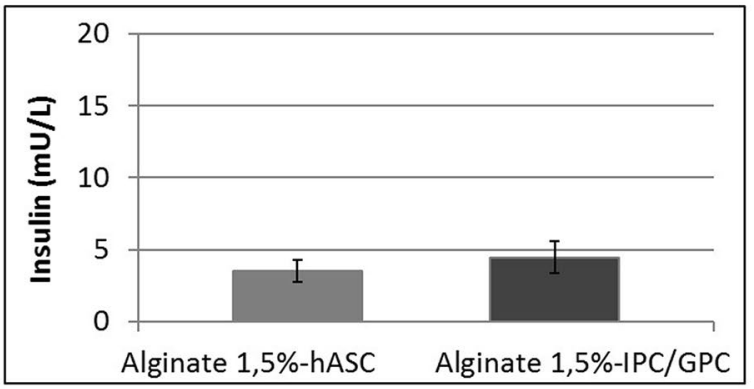

Fig. 6 Characterization of IPC/GCP aggregates in microgels. Light microscopy was performed at different times for a Calcium (upper panel) or Barium (lower panel). $(n=5), \mathbf{b}$ Insulin secretion from microgels at 1 day in $\mathrm{HG}$ conditions $(n=3)$, c Insulin secretion from microgels at 7 days in $\mathrm{HG}$ conditions $(n=3)$. Student's t test, ${ }^{*} p<0.05$. Scale bar $=50 \mu m$

Table 1 Diameter of microencapsulated cell aggregates in $\mathbf{1 . 5 \%}$ sodium alginate

\begin{tabular}{llllll}
\hline Sample & \multicolumn{2}{l}{$\begin{array}{l}\text { Diameter, time } \mathbf{0} \\
(\boldsymbol{\mu} \mathbf{m})\end{array}$} & & \multicolumn{2}{l}{$\begin{array}{l}\text { Diameter } \mathbf{7} \text { days } \\
(\boldsymbol{\mu m})\end{array}$} \\
\cline { 2 - 3 } \cline { 5 - 6 } & $\mathbf{C a C l}_{\mathbf{2}}$ & $\mathbf{B a C l}_{\mathbf{2}}$ & & $\mathbf{C a C l}_{\mathbf{2}}$ & $\mathbf{B a C l}_{\mathbf{2}}$ \\
\hline $\begin{array}{l}\text { Alginate 1.5\%-hASC aggre- } \\
\text { gate }\end{array}$ & $310 \pm 14$ & $303 \pm 23$ & & $459 \pm 28 *$ & $314 \pm 15$ \\
$\begin{array}{l}\text { Alginate 1.5\%-IPC/GPC } \\
\text { aggregate }\end{array}$ & $302 \pm 13$ & $309 \pm 12$ & & $468 \pm 27 *$ & $316 \pm 9$ \\
\hline
\end{tabular}

Sizes of microgels were analysed by Image in at least 10 photographs for each $\mathrm{n}, \mathrm{n}=3,{ }^{*} \mathrm{p}<0.05$

bone marrow (BM-MSC) [33], dental pulp (DPSCs) [34], and placenta [34]. Use of ESC and iPSCs in clinic is not routinely approved due to ethics and implementation considerations. Yet, hASC can be easily obtained from low invasive lipoaspiration procedures with high yield of cell purification. Hence, these cells constitute an important source of MSC $[11,12]$.

The hASC obtained in this work meet the requirements dictated by the International Society of Cell Therapy (ISCT) to classify a cellular population as a
MSC $[27,35,36]$. Our cells were able to adhere to plastic with a fibroblastic phenotype, they expressed CD90, CD73, CD105, CD44, and CD29 while lacking expression of CD45, CD34, CD19 and HLA-DR, concordant to the surface marker expression described for hASC $[11,12]$. Moreover, they were able to differentiate to adipogenic, chondrogenic and osteogenic phenotypes.

We then established a reliable method to induce differentiation of these cells into both IPC and GPC in vitro. Our results agree with those of other groups, in particular the differentiation process of hASC to IPC $[13,14]$. On the other hand, differentiation to GPC has only been reported from ESC [15]. To the best of our knowledge, we are the first group to achieve an efficient and functional GPC differentiation from hASC using the protocol described by Rezania group, yet using SFB $2 \%$ instead of the B27 supplement. For GPC differentiation, we decided to use $2 \%$ FBS instead of $1 \%$ B27 as a supplement in the differentiation medium during stages 3 to 6 (Fig. 1b), a modification reached empirically, which provided more effective differentiation and greater survival, and it also matched the serum concentration used in our subsequent aggregation protocol. In line with these findings, we propose hASC as an 
adequate cellular source to generate IPC and GPC in cell-based therapy against T1DM.

Next, we co-cultured IPC and GPC in a 4:1 ratio by inducing cellular aggregation in low adhesion conditions, as previously described [26]. Using this setting, we observed that cell aggregates increased in size up to $72 \mathrm{~h}$, reaching diameters of $\sim 80 \mu \mathrm{m}$, similar to those reported for human islets $(108 \mu \mathrm{m})$ [37]. Expression of $\alpha$ and $\beta$ pancreatic cell markers in $72 \mathrm{~h}$ old cellular aggregates was also conserved, indicating a strong lineage commitment and low dedifferentiation rate of our cells.

Although human like islets should be able to partially restore the pancreatic endocrine function, the activation of the immune system is still a major limitation, together with the low number of donors for long term treatment $[6,8]$. To overcome this issue, we encapsulated our IPC/ GPC aggregates into sodium alginate microgels using an automatized encapsulator. The size of $\mathrm{Ca}^{2+}$ or $\mathrm{Ba}^{2+}$ stabilized sodium alginate microgels pools were very similar, with very low dispersion. In culture conditions, $\mathrm{Ca}^{2+}$ stabilized microgels increased in size and were less stable then $\mathrm{Ba}^{2+}$ stabilized microgels, which maintained their size and shape even after 7 days of culture. An explanation to this phenomenon lies in the chemical characteristics of the sodium alginate copolymer, which is composed by 1,4-b-D-mannuronic acid (M) and 1,4-a-L-guluronic acid (G) residues, and can be stabilized in general terms by divalent cations being $\mathrm{Ba}^{2+}$ the most efficient $\left(\mathrm{Mg}^{2+} \ll \mathrm{Ca}^{2+}<\mathrm{Sr}^{2+}<\mathrm{Ba}^{2+}\right)[19]$.

Several studies have aimed to improve the output of encapsulated tissue grafts using sodium alginate. However, variables such as alginate purity and immunological response against residual contaminants left from the purification process are still a matter of discussion [19]. In our setting, both $\mathrm{Ca}^{2+}$ or $\mathrm{Ba}^{2+}$ stabilized alginate microgels were able to release both BSA and SpA proteins in the first $5 \mathrm{~min}$, yet after $20 \mathrm{~min}$ the release rate diminished and remained stable. This information defined the alginate microgels pore size, which in essence permits the passage of nutrient such as glucose, as well as small peptides as Ins and Ggc. In agreement with these findings, we also confirmed that our microencapsulated cellular aggregates responded to external glucose by secreting Ins, thus confirming that the microgels allowed the passage of glucose into the microgel to be sensed by the cellular aggregates, which in turn responded by secreting insulin. Also, we observed that undifferentiated hASCs do exhibit a small secretion of insulin in response to external glucose stimulation, which is agreeable with previous reports that explain such phenomena as a result of possible basal, spontaneous differentiation, both in adherent as well as in suspension conditions [38]. It is therefore possible that a small percentage of cells kept in control conditions could have spontaneously differentiated into a pancreatic endocrine phenotype.

Despite the stability of the microgels, IPC/GPC aggregates ceased to secrete insulin after 7 days in culture. This may be attributable to loss of $\beta$ cell function due to a dedifferentiation process, a desensitization of the IPC to glucose, or poor survival of the cellular aggregate in encapsulation conditions in the in vitro environment. Indeed, the described differentiation protocols attempted to reproduce the embryogenic process observed in organs and tissues in vitro. Yet the complexity of the embryogenic process in cell differentiation differs substantially from the much simpler in vitro milieu, a situation that could result in dedifferentiation, and in turn loss of phenotypic and functional characteristics. Nevertheless, an in vivo environment may overcome such limitations. We are currently planning experiments with in vivo implantation of our encapsulated clusters in NOD mice, an animal model of T1DM, which may shed light on this issue.

Our findings enforce the current knowledge on the potential of hASC as a source of multipotent cells in cellular therapy against T1DM. Moreover, we have developed a protocol to generate functional aggregates IPC/ GPC like pancreatic islets, which can be encapsulated in alginate microgels to achieve immunoprotection. In such conditions, the encapsulated aggregates are stable and retain endocrine function in vitro for at least 7 days in culture.

\section{Conclusions}

In the present work, we have achieved in vitro functional differentiation of human multipotent stem cells to IPCs and GPCs. Indeed, we have effectively attained IPCs and GPCs coaggregation to form islet-like clusters, and subsequently microencapsulation in alginate. Cell aggregates retain the capability of expressing endocrine pancreatic markers. Microencapsulation was standardized using a sterile, automated and highly reproducible procedure, thus optimizing protection from eventual immunological rejection after implants. Further, the microcapsules are capable of secreting insulin when subjected to external glucose stimulation.

Finally, the cell coaggregate formation conditions reported herein provide the basis for aggregation of any cell type, projecting its use in other pathologies where replacement of cell mass or function is required. Also, our findings may give rise to new studies, where the functionality of microgels and aggregates can be evaluated in vivo. In this way, the proposed therapy would, on the one hand, immunologically isolate cellular aggregates and, secondly, avoid immunosuppressive treatment. 


\section{Supplementary information}

Supplementary information accompanies this paper at https://doi. org/10.1186/s13098-020-00573-9.

\begin{abstract}
Additional file 1. Materials and Methods. Table S1. Analysis of mesenchymal stem cell markers in hASC by flow cytometry. Table S2. Diameters of microencapsulated BSA and SpA proteins in 1.5\% sodium alginate.
\end{abstract}

Additional file 2: Figure S1. hASC differentiation potential in vitro. Left, Oil red staining for adipogenic phenotype. Center, Von Kossa staining for osteogenic phenotype. Right, Alcian blue stain for condrogenic phenotype. For each staining, control undifferentiated cells (hASC) and differentiated cells using the stempro kit. $n=5$. Scale bar $=10 \mu \mathrm{m}$.

Additional file 3: Figure S2. BSA or SpA release from microgels of sodium alginate $1.5 \%$ stabilized with $\mathrm{Ca}^{2+}$ or $\mathrm{Ba}^{2+}$ to KRB. $\mathrm{n}=3$, no significant differences were found, $p>0.05$.

\section{Acknowledgements}

The authors acknowledge the invaluable technical assistance of Mr. Fernando Guzmán and Mr. Guillermo Elorza.

\section{Authors' contributions}

CJ designed and performed most of the experiments and writing of this manuscript. FO-A provided access to the microencapsulator and feedback on establishing the conditions for microencapsulation of cell clusters and writing of this manuscript. FC provided access to flow cytometry studies and necessary input on mesenchymal cell characterizations, as well as writing of this manuscript. EG-E carried out lipoaspiration procedures and first manipulations of tissue samples and provided input in writing this manuscript. CC provided valuable input in writing this manuscript. PC provided input in all aspects of this work, as well as tutoring $\mathrm{CJ}$ in her work, and in writing this manuscript. All authors read and approved the final manuscript.

\section{Funding}

Claudia Jara, Ph.D. National Scholarship Grant, \# 21110401. Conicyt, Chile. Felipe Oyarzún, FONDECYT 1161450, FONDEQUIP EQM160157, FONDEQUIP EQM170111, CONICYT-FONDAP 15130011. FONDECYT 1201899, ANID/PIA/ ACT192144. Flavio Carrion: Fondecyt 1130444. Pablo Caviedes, FONDECYT Grant \# 1130241, 1161450, CONICYT for funding of Basal Centre, CeBiB, FB0001 and P09-022-F from ICM-ECONOMIA, Chile.

\section{Availability of data and materials}

All data generated or analyzed during this study are included in this published article and enclosed additional information files.

\section{Ethics approval and consent to participate}

The Ethics Committee for research in human of the Faculty of Medicine, University of Chile, approved this project under \# 033-2014, according to the directives of the Helsinki Declaration concerning human rights. Donors consented freely to donate fat tissue for the present study.

\section{Consent for publication}

All authors have reviewed and approved this manuscript, and are aware it is being submitted for publication.

\section{Competing interests}

Pablo Caviedes holds patent protection on the cell aggregation protocol. The remaining authors declare no conflict of interests.

\footnotetext{
Author details

1 Programa de Farmacología Molecular y Clínica, ICBM, Facultad de Medicina Universidad de Chile, Independencia 1027., Casilla 7, Clasificador № 7, 8389100 Santiago, Chile. ${ }^{2}$ Advanced Center of Chronic Diseases (ACCDiS), Universidad de Chile, Santiago, Chile. ${ }^{3}$ Depto. de Ciencias y Tecnología Farmacéuticas, Facultad de Ciencias Químicas y Farmacéuticas, Universidad de Chile, Santiago, Chile. ${ }^{4}$ Programa de Inmunología Traslacional, Facultad de Medicina, Clínica Alemana Universidad del Desarrollo, Santiago, Chile. ${ }^{5}$ Laboratorio de Patología Molecular, Instituto de Bioquímica y Microbiología, Facultad de Ciencias, Universidad Austral de Chile, Valdivia, Chile. ${ }^{6}$ Centro de
}

Biotecnología y Bioingeniería (CeBiB), Departamento de Ingeniería Química, Biotecnología y Materiales, Facultad de Ciencias Físicas y Matemáticas, Universidad de Chile, Santiago, Chile.

Received: 7 April 2020 Accepted: 21 July 2020

Published online: 05 August 2020

\section{References}

1. Ize-Ludlow D, Sperling MA. The classification of diabetes mellitus: a conceptual framework. Pediatr Clin N Am. 2005;52(6):1533-52. https:// doi.org/10.1016/j.pcl.2005.07.001.

2. Rutter GA, Hodson DJ. Minireview: intraislet regulation of insulin secretion in humans. Mol Endocrinol. 2013;27(12):1984-95. https://doi. org/10.1210/me.2013-1278.

3. Shapiro AM, Ricordi C, Hering BJ, et al. International trial of the Edmonton protocol for islet transplantation. N Engl J Med. 2006;355(13):1318-30. https://doi.org/10.1056/NEJMoa061267.

4. Shapiro AM, Lakey JR, Ryan EA, et al. Islet transplantation in seven patients with type 1 diabetes mellitus using a glucocorticoid-free immunosuppressive regimen. N Engl J Med. 2000;343(4):230-8. https://doi. org/10.1056/NEJM200007273430401.

5. Ryan EA, Lakey JR, Rajotte RV, et al. Clinical outcomes and insulin secretion after islet transplantation with the Edmonton protocol. Diabetes. 2001;50(4):710-9. https://doi.org/10.2337/diabetes.50.4.710.

6. Ryan EA, Paty BW, Senior PA, Shapiro AM. Risks and side effects of islet transplantation. Curr Diabetes Rep. 2004;4(4):304-9. https://doi. org/10.1007/s11892-004-0083-8.

7. Vincenti F, Friman S, Scheuermann E, et al. Results of an international, randomized trial comparing glucose metabolism disorders and outcome with cyclosporine versus tacrolimus. [published correction appears in Am J Transplant. 2008;8(4):908. Dosage error in article text] [published correction appears in Am J Transplant. 2008;8(1):1]. Am J Transplant. 2007;7(6):1506--1514. https://doi.org/10.1111/j.1600-6143.2007.01749.x.

8. Ichii H, Ricordi C. Current status of islet cell transplantation. J Hepatobiliary Pancreat Surg. 2009;16(2):101-12. https://doi.org/10.1007/s0053 4-008-0021-2.

9. Matsumoto S, Abalovich A, Wechsler C, Wynyard S, Elliott RB. Clinical benefit of islet xenotransplantation for the treatment of type 1 diabetes. EBioMedicine. 2016;12:255-62. https://doi.org/10.1016/j.ebiom.2016.08.034.

10. da Silva Meirelles L, Chagastelles PC, Nardi NB. Mesenchymal stem cells reside in virtually all post-natal organs and tissues. J Cell Sci. 2006;119(Pt 11):2204-13. https://doi.org/10.1242/jcs.02932.

11. Kern S, Eichler H, Stoeve J, Klüter H, Bieback K. Comparative analysis of mesenchymal stem cells from bone marrow, umbilical cord blood, or adipose tissue. Stem Cells. 2006;24(5):1294-301. https://doi.org/10.1634/ stemcells.2005-0342.

12. Heo JS, Choi Y, Kim HS, Kim HO. Comparison of molecular profiles of human mesenchymal stem cells derived from bone marrow, umbilical cord blood, placenta and adipose tissue. Int J Mol Med. 2016;37(1):11525. https://doi.org/10.3892/ijmm.2015.2413.

13. Mohamad Buang ML, Seng HK, Chung LH, Saim AB, Idrus RB. In vitro generation of functional insulin-producing cells from lipoaspirated human adipose tissue-derived stem cells. Arch Med Res. 2012;43(1):83-8. https:// doi.org/10.1016/j.arcmed.2012.01.012.

14. Kang HM, Kim J, Park S, et al. Insulin-secreting cells from human eyelidderived stem cells alleviate type I diabetes in immunocompetent mice. Stem Cells. 2009;27(8):1999-2008. https://doi.org/10.1002/stem.127.

15. Rezania A, Riedel MJ, Wideman RD, et al. Production of functional glucagon-secreting a-cells from human embryonic stem cells. Diabetes. 2011;60(1):239-47. https://doi.org/10.2337/db10-0573.

16. Timper $K$, Seboek D, Eberhardt M, et al. Human adipose tissue-derived mesenchymal stem cells differentiate into insulin, somatostatin, and glucagon expressing cells. Biochem Biophys Res Commun. 2006;341(4):1135-40. https://doi.org/10.1016/j.bbrc.2006.01.072.

17. Chandra V, Swetha G, Muthyala S, et al. Islet-like cell aggregates generated from human adipose tissue derived stem cells ameliorate experimental diabetes in mice. PLoS ONE. 2011;6(6):e20615. https://doi. org/10.1371/journal.pone.0020615. 
18. Watts $\mathrm{M}, \mathrm{Ha}$ J, Kimchi $\mathrm{O}$, Sherman A. Paracrine regulation of glucagon secretion: the $\beta / \alpha / \delta$ model. Am J Physiol Endocrinol Metab. 2016;310(8):E597-611. https://doi.org/10.1152/ajpendo.00415.2015.

19. Paredes Juárez GA, Spasojevic M, Faas MM, de Vos P. Immunological and technical considerations in application of alginate-based microencapsulation systems. Front Bioeng Biotechnol. 2014;2:26. https://doi. org/10.3389/fbioe.2014.00026.

20. Safley SA, Cui H, Cauffiel S, Tucker-Burden C, Weber CJ. Biocompatibility and immune acceptance of adult porcine islets transplanted intraperitoneally in diabetic NOD mice in calcium alginate poly-L-lysine microcapsules versus barium alginate microcapsules without poly-L-lysine. J Diabetes Sci Technol. 2008;2(5):760-7. https://doi.org/10.1177/19322 9680800200503.

21. Schneider S, Feilen PJ, Brunnenmeier F, et al. Long-term graft function of adult rat and human islets encapsulated in novel alginate-based microcapsules after transplantation in immunocompetent diabetic mice. Diabetes. 2005;54(3):687-93. https://doi.org/10.2337/diabetes.54.3.687.

22. Omer A, Duvivier-Kali V, Fernandes J, Tchipashvili V, Colton CK, Weir GC. Long-term normoglycemia in rats receiving transplants with encapsulated islets. Transplantation. 2005;79(1):52-8. https://doi.org/10.1097/01. tp.0000149340.37865.46.

23. Qi M, Strand BL, Mørch Y, et al. Encapsulation of human islets in novel inhomogeneous alginate-ca2+/ba2+ microbeads: in vitro and in vivo function. Artif Cells Blood Substit Immobil Biotechnol. 2008;36(5):402-3. https://doi.org/10.1080/10731190802369755.

24. Cabané P, Gac P, Amat J, et al. Allotransplant of microencapsulated parathyroid tissue in severe postsurgical hypoparathyroidism: a case report. Transplant Proc. 2009;41(9):3879-83. https://doi.org/10.1016/j.transproce ed.2009.06.211.

25. Toledo PC, Rossi RL, Caviedes P. Microencapsulation of parathyroid cells for the treatment of hypoparathyroidism. Methods Mol Biol. 2017;1479:357-63. https://doi.org/10.1007/978-1-4939-6364-5_27.

26. Caviedes P, Caviedes R, Freeman T, et al. Pub US Patent No 7323333 B2. 2008.

27. Hassan N, Oyarzun-Ampuero F, Lara P, Guerrero S, Cabuil V, AbouHassan A, Kogan MJ. Flow chemistry to control the synthesis of nano and microparticles for biomedical applications. Curr Top Med Chem. 2014;14(5):676-89. https://doi.org/10.2174/15680266146661401182 13915.

28. Inostroza-Riquelme M, Vivanco A, Lara P, Guerrero S, Salas-Huenuleo E, Chamorro A, Leyton L, Bolaños K, Araya E, Quest AFG, Kogan MJ, Oyarzun-Ampuero F. Encapsulation of gold nanostructures and oil-inwater nanocarriers in microgels with biomedical potential. Molecules. 2018;23(5):1208. https://doi.org/10.3390/molecules23051208.
29. Wang N, Adams G, Buttery L, Falcone FH, Stolnik S. Alginate encapsulation technology supports embryonic stem cells differentiation into insulin-producing cells. J Biotechnol. 2009;144(4):304-12. https://doi. org/10.1016/j.jbiotec.2009.08.008.

30. Dominici M, Le Blanc K, Mueller I, et al. Minimal criteria for defining multipotent mesenchymal stromal cells. The International Society for Cellular Therapy position statement. Cytotherapy. 2006;8(4):315-7. https://doi. org/10.1080/14653240600855905.

31. Hua XF, Wang YW, Tang YX, et al. Pancreatic insulin-producing cells differentiated from human embryonic stem cells correct hyperglycemia in SCID/NOD mice, an animal model of diabetes. PLoS ONE. 2014;9(7):e102198. https://doi.org/10.1371/journal.pone.0102198.

32. Jeon K, Lim H, Kim JH, et al. Differentiation and transplantation of functional pancreatic beta cells generated from induced pluripotent stem cells derived from a type 1 diabetes mouse model. Stem Cells Dev. 2012;21(14):2642-55. https://doi.org/10.1089/scd.2011.0665.

33. Gabr MM, Zakaria MM, Refaie AF, et al. Insulin-producing cells from adult human bone marrow mesenchymal stem cells control streptozotocininduced diabetes in nude mice. Cell Transplant. 2013;22(1):133-45. https ://doi.org/10.3727/096368912X647162.

34. Carnevale G, Riccio M, Pisciotta A, et al. In vitro differentiation into insulinproducing $\beta$-cells of stem cells isolated from human amniotic fluid and dental pulp. Dig Liver Dis. 2013;45(8):669-76.

35. González E, Carrión F, Caviedes P. The UCHT1 method have a proliferative effect in human adipose stem cells (hASC). In: 1st national congress of tissue engineering and regenerative medicine, LAP LAMBERT Academic Publishing, Mauritius. 2018. pp. 77-79. ISBN 978-613-3-99514-7.

36. Bourin P, Bunnell BA, Casteilla $L$, et al. Stromal cells from the adipose tissue-derived stromal vascular fraction and culture expanded adipose tissue-derived stromal/stem cells: a joint statement of the International Federation for Adipose Therapeutics and Science (IFATS) and the International Society for Cellular Therapy (ISCT). Cytotherapy. 2013;15(6):641-8. https://doi.org/10.1016/j.jcyt.2013.02.006.

37. Ionescu-Tirgoviste C, Gagniuc PA, Gubceac E, et al. A 3D map of the islet routes throughout the healthy human pancreas. Sci Rep. 2015;5:14634. https://doi.org/10.1038/srep14634.

38. Assady S, Maor G, Amit M, Itskovitz-Eldor J, Skorecki KL, Tzukerman M. Insulin production by human embryonic stem cells. Diabetes. 2001;50(8):1691-7. https://doi.org/10.2337/diabetes.50.8.1691.

\section{Publisher's Note}

Springer Nature remains neutral with regard to jurisdictional claims in published maps and institutional affiliations.
Ready to submit your research? Choose BMC and benefit from:

- fast, convenient online submission

- thorough peer review by experienced researchers in your field

- rapid publication on acceptance

- support for research data, including large and complex data types

- gold Open Access which fosters wider collaboration and increased citations

- maximum visibility for your research: over $100 \mathrm{M}$ website views per year

At BMC, research is always in progress.

Learn more biomedcentral.com/submissions 